Article

\title{
Weed Control Ability of Single Sown Cover Crops Compared to Species Mixtures
}

\author{
Alexandra Schappert*(D), Matthias Schumacher ${ }^{(D)}$ and Roland Gerhards \\ Department of Weed Science, Institute of Phytomedicine, University of Hohenheim, 70599 Stuttgart, Germany; \\ matthias.schumacher@uni-hohenheim.de (M.S.); Roland.Gerhards@uni-hohenheim.de (R.G.) \\ * Correspondence: Alexandra.Schappert@uni-hohenheim.de; Tel.: +49-711-459-23444
}

Received: 3 May 2019; Accepted: 3 June 2019; Published: 6 June 2019

check for

updates

\begin{abstract}
To achieve efficient weed control through cover cropping, the plant species chosen needs particular consideration. Combing different cover crop (CC) species in mixtures may increase the number of provided ecosystem services, including reliable suppression of weeds. We tested the weed suppression ability of single CC species and CC mixtures in a field trial during the autumn-to-winter growing season of 2016 and 2017. Anethum graveolens L. (dill), Raphanus sativus var. oleiformis Pers. (oilseed radish), Avena strigosa Schreb. (black oat), Carthamus tinctorius L. (safflower), Vicia sativa L. (vetch) and Phacelia tanacetifolia Benth. (phacelia) were sown in monocultures, as well as in mixtures with three or six species. Treatments with favorable establishment and above-average biomass yields tended to suppress weeds by showing lower weed dry matter and weed numbers. The highest weed control efficacy within the monocultures was reached in 2017 by black oat and oilseed radish with $72 \%$ and $83 \%$, respectively. The mixture treatments reached a generally lower soil cover, aboveground dry matter and weed control efficacy (with an average of 57\% in 2017). Even though mixtures were not as effective as the best performing single sown CCs, species combinations increased resilience against adverse weather conditions, an advantage to achieving efficient weed control over a long-term period. Therefore, species composition within mixtures is more relevant than the number of species included.
\end{abstract}

Keywords: biological; catch crop; plant diversity; weed management

\section{Introduction}

The incorporation of cover crops (CCs) into crop rotations has become a practical strategy by producers. The European Union further promotes the use of CCs in agriculture by their "greening" strategy [1]. The increasing interest of producers and researchers in CCs might have been encouraged by the manifold positive aspects which are attributed to cover cropping. CCs are normally grown between two main crops to reduce erosion and to improve soil characteristics like nitrogen content, phosphor availability and soil structure [2]. Additionally, they serve as a pollen and nectar source for pollinators and overwintering habitat for beneficials [3,4]. They also provide services that reduce pests, pathogens and weeds [5,6]. CCs offer different temporal and spatial (niche) possibilities as well as physical and biochemical mechanisms to control weeds.

After sowing, CCs provide direct weed control during their establishment by releasing allelochemical compounds into the environment [7] and competing with weeds for light, water, nutrients and space [8]. This can severely hamper the development of weeds [9] or even prevent them from emerging. Some cover crop (CC) species are able to survive the harsh conditions over winter and continue to provide this service in early spring. CCs are normally terminated by mechanical or chemical methods before sowing of the next main crop. In any case, CC residues are either incorporated into the soil or retained on the soil surface [10]. Under both strategies, plant residues continue to release the remaining allelochemicals that are contained in the dead plant material [11,12]. If CC residues 
are left on the soil surface, they additionally act as a physical layer that small weed seedlings need to penetrate $[13,14]$. This slows down the development of the weed populations in spring after the main crop has already been sown [15]. Therefore, CCs are able to affect weed populations from their sowing date until a certain time after the subsequent main crop is established [16]. Naturally, the weed suppressive ability of a CC depends on several environmental influences that determine, e.g., the level and activity of allelochemicals [17], the speed of CC development and the build-up of biomass [18]. Under unfavorable conditions, a single sown CC might not be able to provide a sufficient level of weed suppression.

Crop stands of single CC species are not able to buffer rapidly changing environmental conditions. Therefore, many studies have investigated the adaptability of mixtures [19-21]. Higher species diversity increases the likelihood that some of the species in a mixture are more productive, because they are better adapted to a certain set of environmental conditions (sampling effect) [22,23]. The CC species Vicia sativa L. and Phacelia tanacetifolia Benth. were not germinating well under high temperatures, whereas Guizotia abyssinica (L.f.) Cass. performed well [24]. Combinations of contrasting species in regard to environmental conditions, therefore, might provide resilience to weather conditions and provide stability in their service provision. The conditions that drive CC species performance are also dependent on agronomic measures such as sowing date and termination method [25]. CC mixtures might not only be resilient to environmental conditions, but also to failures in the conductance of agronomic measures by the producer. One of the upcoming major challenges will be the handling of climate change and extreme weather events in agriculture [26] and the question of how to design appropriate CC mixtures to deal with them.

Additionally, more diverse mixtures host species that have different acquisition and competition strategies. The "niche complementarity" [27] describes the actual function of a mixture based on the traits of the single species. The more diverse or different the setup of these traits for every single species within a mixture, the more likely it is that they occupy different niches and are more productive. CC species with different plant canopy features might intercept and use light more efficiently and therefore reduce the availability of light on the soil surface, leading to a reduced emergence of weeds. The unique root growth patterns and abilities to take up and mobilize nutrients in the soil by CC species in mixtures might be able to use nutrients more efficiently and consequently leave fewer resources for weeds $[28,29]$. Regarding weed suppressive abilities, cereal species are often more effective than legume species [30-32], which makes the former preferable components of CC mixtures dedicated to controlling weeds while the latter can add value by fixing nitrogen. It might also be possible to combine CC species with predominant physical or biochemical effects to further enhance the weed control abilities of these mixtures. Poaceae and Brassicaceae species have proven to be allelopathic [2,17], while others like vetch (Vicia villosa Roth) seem to act predominantly via competition [33]. As the weed control efficiency is dependent on both of these effects, the use of CC mixtures was already advised and examined by several authors [32,34]. One, yet unsolved, issue is how to separate between competition and biochemical effects and their contribution to weed control in the field $[35,36]$. Another important question is: which traits of CCs are affecting their level of weed control? The usual reasoning that higher biomass production leads to a higher competitive ability and therefore more efficient weed control [37] might not hold true in all cases. Several recent studies reported no correlation between biomass and weed reduction $[32,34]$. There might be other or additional factors that may determine the level of weed control.

Sampling effect and niche complementarity have been examined well in natural plant communities [38,39], but also to some extend for agricultural systems [40,41]. All these systems, natural and agricultural alike, perform ecosystem services based on the functions that the plants provide and these are often enhanced if species diversity is increased. A combination of the effects of species mixtures with the multiple advantages that CCs offer, can result in a very productive CC stand. This productivity does not normally lead to a harvest good, but might enhance the services provided by the CCs [42]. How many CC species or which particular traits are necessary to ensure 
weed control is still under investigation [32,43-45]. Ultimately, carefully designed species mixtures may be more stable in terms of weed control efficiency and reaction to changing weather conditions than single sown CCs, providing reassurance for the producer. Recognizing this great potential of CC mixtures along with the still scarce knowledge on service provision and reaction to climate, this study investigated the weed control ability of single sown CCs and CC mixtures in two very contrasting years. Within the study, the following hypotheses were investigated: (i) CC dry matter does not determine the weed suppression ability; (ii) mixtures have a better ability to suppress weeds in comparison to CC monocultures; (iii) species-rich mixtures suppress weeds more efficiently than species-poor mixtures.

\section{Materials and Methods}

\subsection{Experimental Sites}

The experimental field trials were conducted at the research station of the University of Hohenheim ( $48.74^{\circ} \mathrm{N}, 8.92^{\circ} \mathrm{E}, 475 \mathrm{~m}$ a.s.l.) in Southwest-Germany from August until December 2016 and 2017. After CC sowing in 2016 a long dry period followed. During the cover cropping season in 2017 the frequency and the amount of water provided ideal growing conditions for the CCs (Figure 1).

2016

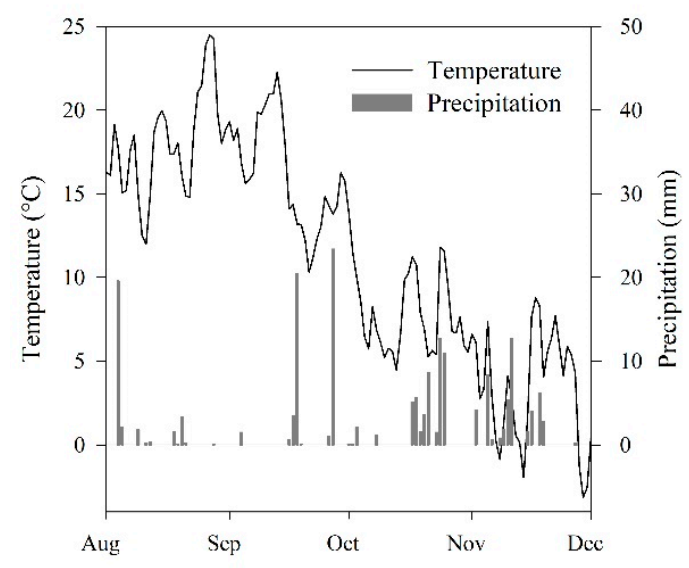

(a)
2017

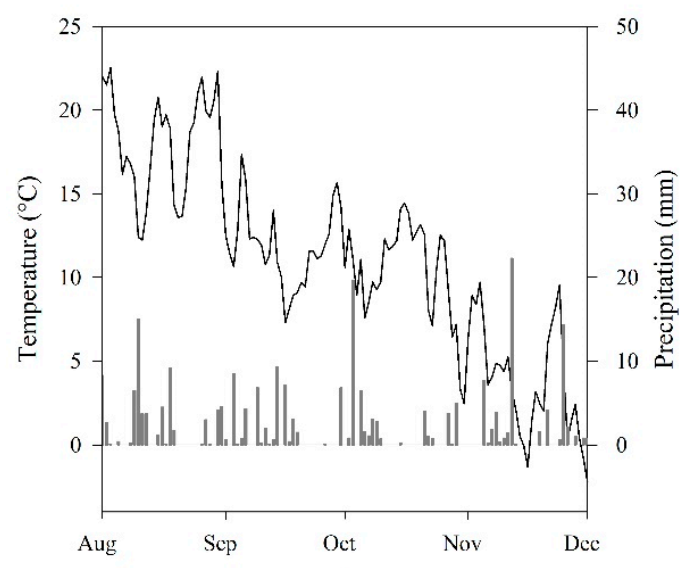

(b)

Figure 1. Temperature and precipitation from August to December 2016 (a) and 2017 (b).

The soil type at the field site during the season 2016 was classified as a silty clay ( $6 \%$ sand, 53\% silt and $41 \%$ clay). During the 2017 season, the field site was classified as a silty loamy soil (27\% sand, $48 \%$ silt and $25 \%$ clay). Table 1 shows details about the crop rotation and field preparations.

Table 1. Experimental set-up and conditions for the field trials in Southwest Germany in 2016 and 2017.

\begin{tabular}{ccc}
\hline & 2016 & 2017 \\
\hline Crop rotation & Winter wheat-cover crop & Winter barley-cover crop \\
Cereal harvest date & 8 August 2016 & 5 August 2017 \\
& Stubble cultivator + & Stubble cultivator + \\
Soil preparation (depth) & deep tillage $(15 \mathrm{~cm})+$ & deep tillage $(15 \mathrm{~cm})+$ \\
Sowing date & power harrow $(6-8 \mathrm{~cm})$ & power harrow $(6-8 \mathrm{~cm})$ \\
Sowing depth & 19 August 2016 & 25 August 2017 \\
& $2 \mathrm{~cm}$ & $2 \mathrm{~cm}$ \\
\hline
\end{tabular}

Six CCs (provided by Deutsche Saatveredelung AG (DSV)): Anethum graveolens L. (A. graveolens), Raphanus sativus var. oleiformis Pers. (R. sativus), Avena strigosa Schreb. (A. strigosa), Carthamus tinctorius L. (C. tinctorius), Vicia sativa L. (V. sativa) and Phacelia tanacetifolia Benth. (P. tanacetifolia) were sown in both years (Table 2) in monocultures and in five mixtures including the same species as for the 
monocropping treatments. The untreated control treatment was left as a weed fallow without CCs. The mixing ratios refer to the seed weight and recommend seeding densities as for the single sown CCs.

Table 2. Twelve treatments including an untreated control treatment without cover crops, six single sown cover crops and five cover crop mixtures.

\begin{tabular}{ccc}
\hline Treatment & Crop Species & Seed Density (kg ha $\mathbf{~}^{\mathbf{1}}$ ) \\
\hline Control & Without cover crops & - \\
A. graveolens & Single sown Anethum graveolens L. & 25 \\
R. sativus & Single sown Raphanus sativus var. oleiformis Pers. & 25 \\
A. strigosa & Single sown Avena strigosa Schreb. & 120 \\
C. tinctorius & Single sown Carthamus tinctorius L. & 40 \\
V. sativa & Single sown Vicia sativa L. & 100 \\
P. tanacetifolia & Single sown Phacelia tanacetifolia Benth. & 10 \\
Mixture 1 & Mixture with 33\% A. graveolens, 33\% R. sativus, 33\% A. strigosa & 57 \\
Mixture 2 & Mixture with 33\% P. tanacetifolia, 33\% C. tinctorius, 33\% V. sativa & 50 \\
Mixture 3 & $50 \%$ Mixture 1, 50\% Mixture 2 & 53 \\
Mixture 4 & 20\% Mixture 1, 80\% Mixture 2 & 51 \\
Mixture 5 & 80\% Mixture 1, 20\% Mixture 2 & 55 \\
\hline
\end{tabular}

\subsection{Data Collection}

Percent of soil coverage by CCs was estimated four times in a $0.1 \mathrm{~m}^{2}$ area randomly selected in each plot. Soil coverage was recorded seven (2016) and four times (2017) after sowing until 12 weeks after sowing (WAS). Seven and 12 WAS the weed density and community were determined. Fresh matter of CCs and weeds was cut 7 and 12 WAS within an area of $0.25 \mathrm{~m}^{2}$. The fresh matter was cleaned with water and afterwards placed in the oven at $100{ }^{\circ} \mathrm{C}$ for $24 \mathrm{~h}$ to obtain biomass on a dry matter basis.

\subsection{Data Analysis}

The data were analyzed with the software R (Version 3.5.1). Normal distribution and homogeneity of variance were visually checked before analyzing the data. Linear regression was used to test for correlations. A log data transformation, prior to using an analysis of variance (ANOVA), was necessary for the weed density (12 WAS 2017) data. Means of different treatments were compared using the Tukey-HSD test $(p \leq 0.05)$. According to Rasmussen et al. [46], the weed control efficacy (WCE) based on the weed density was calculated as

$$
\operatorname{WCE}(\%)=100-w t(0.01 \times w c)^{-1}
$$

where by $w t$ is the weed density (weeds $\mathrm{m}^{-2}$ ) of the weed management treatments and $w c$ the weed density (weeds $\mathrm{m}^{-2}$ ) of the untreated control.

\section{Results}

\subsection{Cover Crop and Weed Development}

At the beginning of the CC growing season in 2016, the R. sativus and P. tanacetifolia treatments displayed the highest soil cover among the single sown CCs (Figure 2). The P. tanacetifolia treatment had the highest soil cover $(79 \%)$ during the beginning of November while $R$. sativus reached a maximum of 50\% soil cover during this same period. In 2017, the A. strigosa and the P. tanacetifolia treatments reached the highest soil cover among all treatments with a maximum of 92 and $83 \%$, respectively, in late November. The mixtures generally showed less soil cover than the best performing single sown CC treatments in both years. The soil cover of the mixtures was generally quite homogeneously distributed and ranged between 39-67\% (4 November) in 2016 and 68-79\% (15 November) in 2017. 


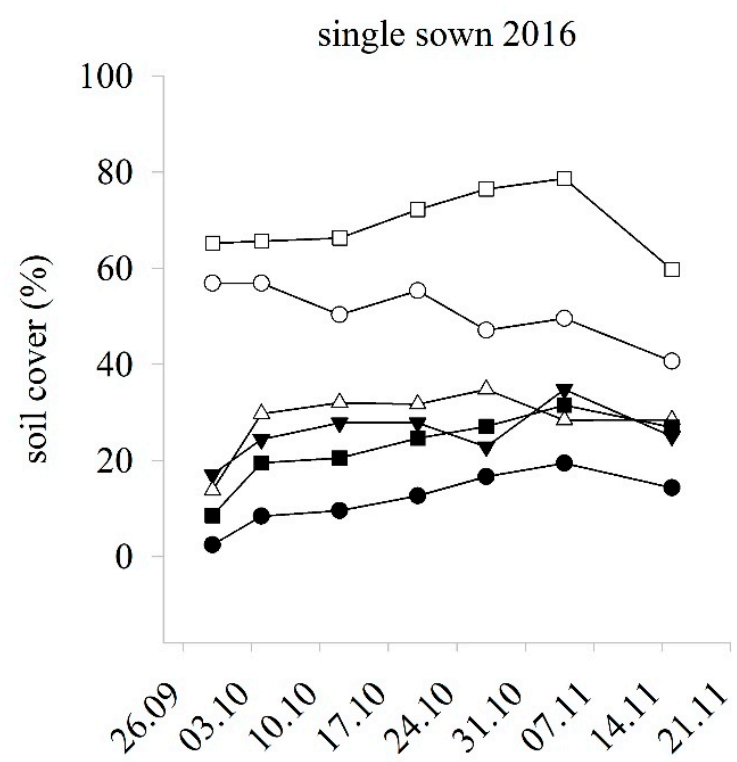

(a)

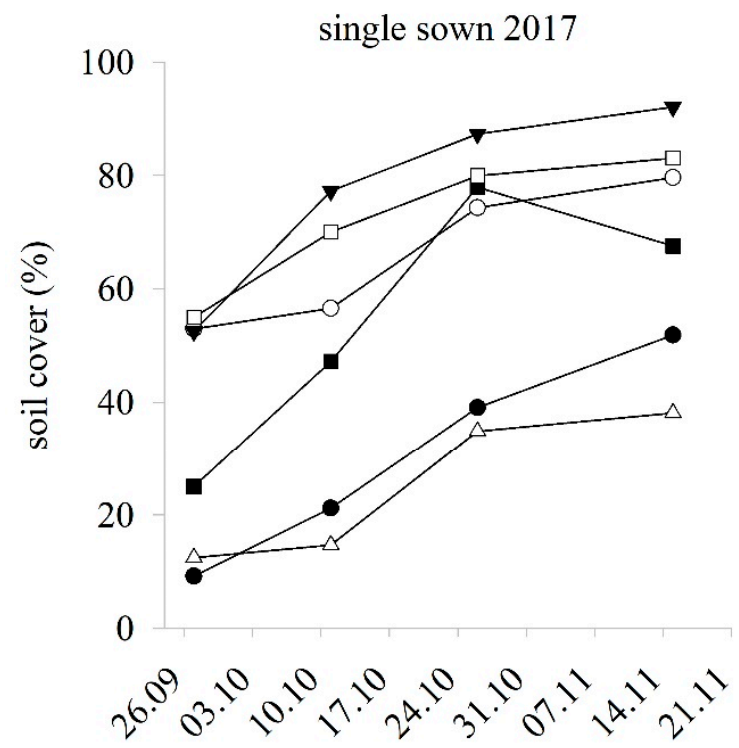

(c)

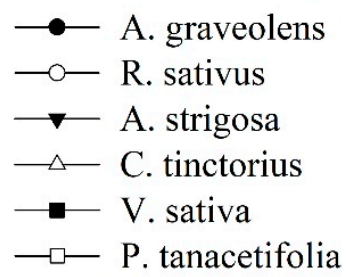

mixtures 2016

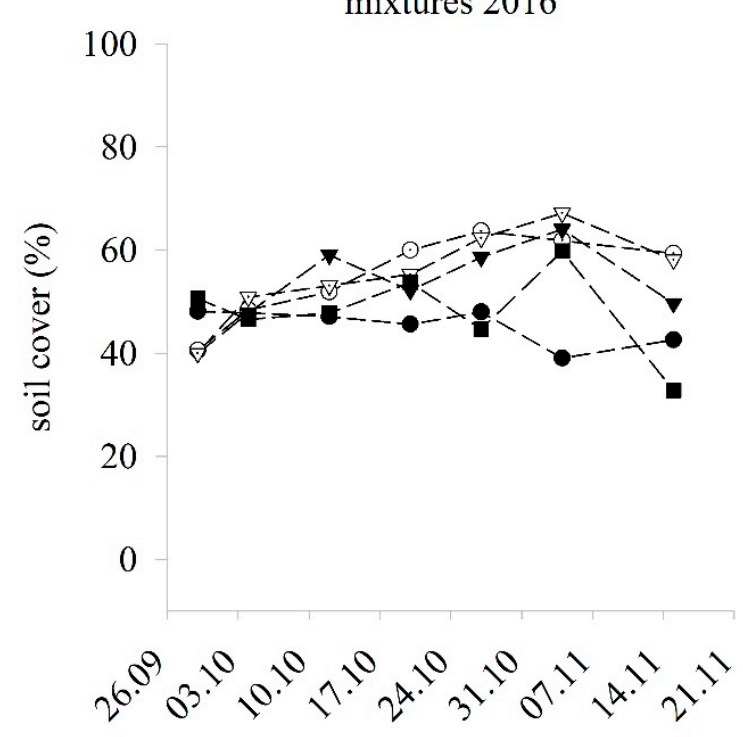

(b)
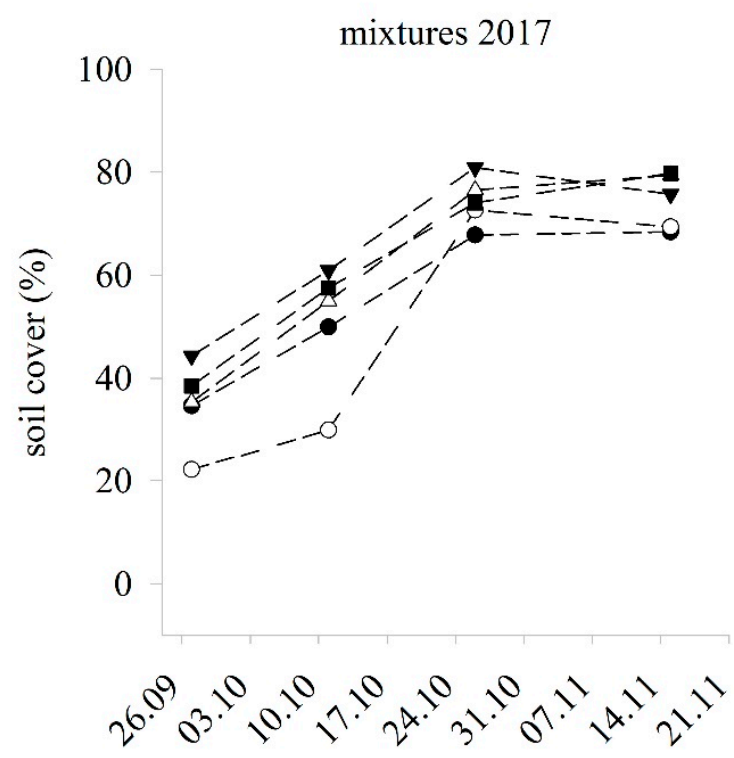

(d)

Figure 2. Cover crop soil cover (\%) for the six single sown cover crops $(\mathbf{a}, \mathbf{c})$ and the five mixtures $(\mathbf{b}, \mathbf{d})$ from the end of September until the end of November in $2016(\mathbf{a}, \mathbf{b})$ and $2017(\mathbf{c}, \mathbf{d})$. Dates in the $x$-axis in the format dd.MM.

In both years, volunteer crops like Brassica napus L. (2016), Triticum aestivum L. (2016) and Hordeum vulgare L. (2017) belonged to the dominant weeds. Dicotyledonous weeds were the dominant weed species in addition to volunteer crops. In 2016, the dominant weed species were Galium aparine L., Chenopodium album L., Veronica persica Poir. and Capsella bursa-pastoris (L.) Medik.. In 2017, there 
was a broader species diversity, including species like Matricaria spp., Lamium purpureum L., Capsella bursa-pastoris (L.) Medik., Veronica persica Poir., Stellaria media Vill., Chenopodium album L. and Cirsium arvense (L.) Scop. The untreated control treatment in 2016 showed a mean weed infestation of 62.5 plants $\mathrm{m}^{-2}$ (Table 3). In 2017, the untreated control showed a 10-times higher (678.8 plants $\mathrm{m}^{-2}$ 12 WAS) weed density than in 2016. In 2016, the significantly lowest number of weeds was counted in the R. sativus (13.1 plants $\mathrm{m}^{-2}$ ) and Mixture 4 (14.4 plants $\mathrm{m}^{-2}$ ) treatments. In 2017, the significantly lowest number of weeds was observed in the $A$. strigosa treatment with 112.5 plants $\mathrm{m}^{-2}$. Similarly, high weed densities as in the untreated control were counted in the A. graveolens, C. tinctorius and $V$. sativa treatments, which had shown a generally weak performance within the two years regarding CC soil cover and CC dry matter. There were no significant differences between any treatments concerning total weed density 7 WAS in 2017.

Table 3. Total weed density for the six single sown and five cover crop mixtures 12 weeks after sowing in 2016 and 2017. Different capital letters within one column show significant differences according to Tukey-HSD test $(p \leq 0.05)$.

\begin{tabular}{ccc}
\hline Treatments & Total Weed Density (Plants $\mathbf{~}^{-\mathbf{2}}$ ) \\
\hline & 2016 & 2017 \\
Control & $62.5^{\mathrm{A}}$ & $678.8^{\mathrm{A}}$ \\
A. graveolens & $49.9^{\mathrm{AB}}$ & $433.8^{\mathrm{ABC}}$ \\
R. sativus & $13.1^{\mathrm{C}}$ & $196.6^{\mathrm{BC}}$ \\
A. strigosa & $29.4^{\mathrm{BC}}$ & $112.5^{\mathrm{C}}$ \\
C. tinctorius & $41.9^{\mathrm{ABC}}$ & $452.5^{\mathrm{ABC}}$ \\
V. sativa & $37.5^{\mathrm{ABC}}$ & $483.8^{\mathrm{AB}}$ \\
P. tanacetifolia & $20.0^{\mathrm{BC}}$ & $382.5^{\mathrm{ABC}}$ \\
Mixture 1 & $30.0^{\mathrm{BC}}$ & $168.8^{\mathrm{BC}}$ \\
Mixture 2 & $25.6^{\mathrm{BC}}$ & $370.0^{\mathrm{ABC}}$ \\
Mixture 3 & $28.8^{\mathrm{BC}}$ & $326.3^{\mathrm{ABC}}$ \\
Mixture 4 & $14.4^{\mathrm{C}}$ & $237.5^{\mathrm{ABC}}$ \\
Mixture 5 & $27.5^{\mathrm{BC}}$ & $272.5^{\mathrm{ABC}}$ \\
\hline
\end{tabular}

The weed densities 12 WAS in 2016 and 2017 showed a correlation with an $R^{2}$ of 0.58 . The regression between those two parameters was significant $(p=0.004)$, which shows that the occurrence of weeds within the treatments was not random within both years.

Due to the four weeks of drought after sowing in 2016, the CCs were only sparsely developed 7 WAS (Figure 3a). The R. sativus treatment reached the significantly highest aboveground dry matter (1210 kg ha $\left.{ }^{-1}\right) 7$ WAS in 2016. Except for the A. graveolens and Mixture 2 treatment, all treatments were able to significantly reduce the dry matter amount of weeds (7 WAS) compared to the untreated control. The generally low weed infestation and the poor growing conditions in 2016 season led to a maximum weed dry matter of $206 \mathrm{~kg} \mathrm{ha}^{-1}$.

None of the CC treatments were able to show a significantly lower weed dry matter than the untreated control 12 WAS in 2016 (Figure 3b). The R. sativus and P. tanacetifolia treatments reached the significantly highest amount of CC dry matter within the single sown species with 1626 and $2068 \mathrm{~kg} \mathrm{ha}^{-1}$, respectively. Among all treatments, Mixture 2 and 3 achieved with 2396 and $2350 \mathrm{~kg} \mathrm{ha}^{-1}$ the highest amount of CC dry matter.

The amount of weed dry matter of the untreated control 7 WAS in 2017 was, with $467 \mathrm{~kg} \mathrm{ha}^{-1}$, almost twice as high as 7 WAS in 2016 (Figure 3c). Among the single sown CCs, only the treatments R. sativus and A. strigosa, with 1247 and $1450 \mathrm{~kg} \mathrm{ha}^{-1}$ aboveground dry matter, respectively, were able to significantly reduce the amount of weed dry matter compared to the untreated control 7 WAS in 2017. Compared to the untreated control all mixtures, except for Mixture 2, significantly reduced the weed dry matter. 
In 2017, the $P$. tanacetifolia treatment had the highest amount of CC dry matter with $2247 \mathrm{~kg} \mathrm{ha}^{-1}$ but did not significantly reduce the amount of weed dry matter compared to the untreated control 12 WAS (Figure 3d). The treatment $A$. strigosa showed the lowest amount of weed dry matter with $97 \mathrm{~kg} \mathrm{ha}^{-1}$ among all treatments and reached an aboveground dry matter of $2197 \mathrm{~kg} \mathrm{ha}^{-1}$. The mixtures, except for Mixture 4, were able to significantly reduce the dry matter of weeds compared to the untreated control, but showed generally lower numbers of CC dry matter compared to the previous year, reaching a maximum of $1674 \mathrm{~kg} \mathrm{ha}^{-1}$ (Mixture 1).
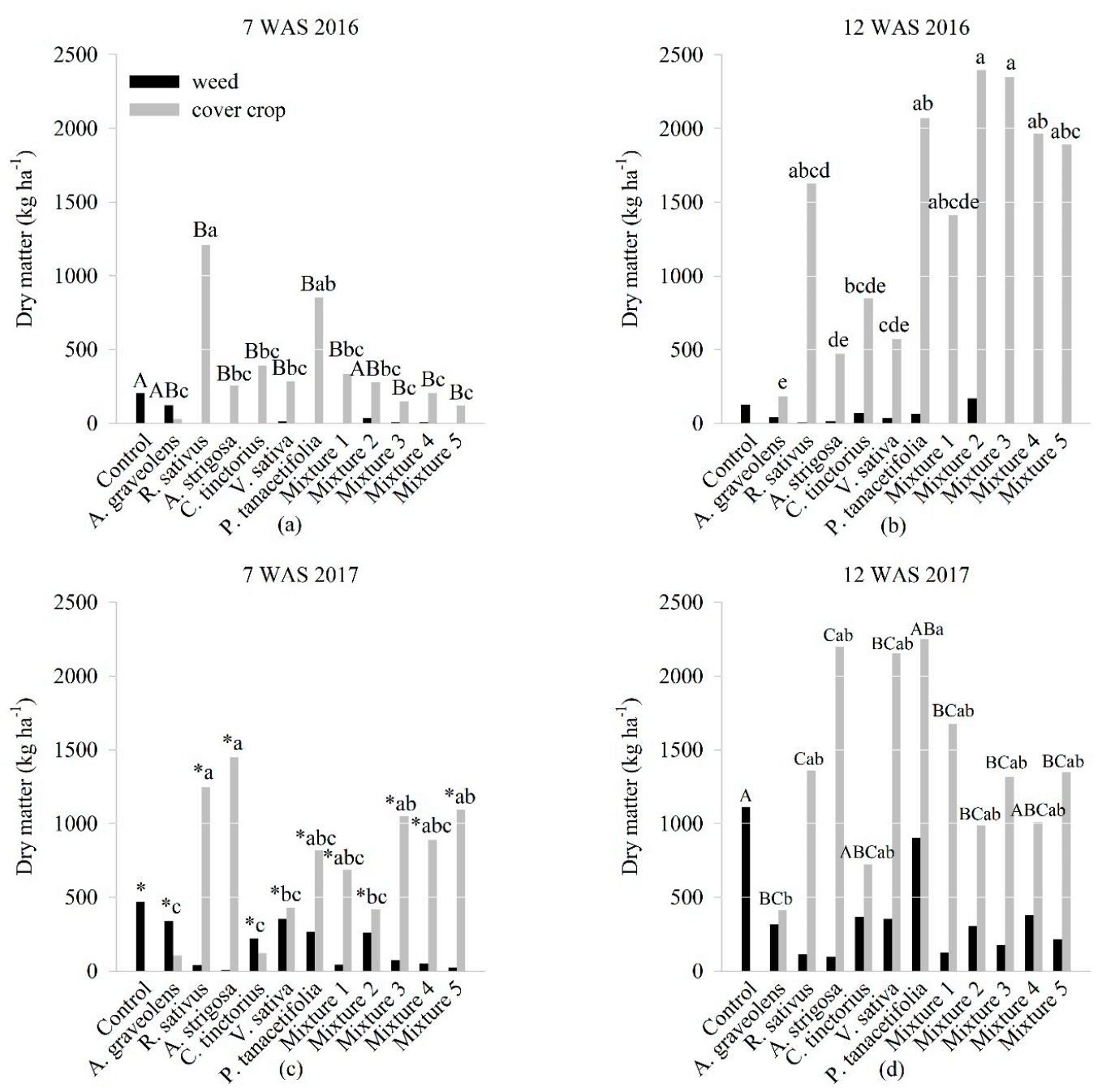

Figure 3. Cover crop (grey) and weed (black) aboveground dry matter in $\mathrm{kg} \mathrm{ha}^{-1}$ for the six single sown and five cover crop mixtures 7 weeks after sowing (WAS) in 2016 (a)/2017 (c) and 12 WAS in 2016 (b)/2017 (d). Different small letters within one graph show significant differences concerning the cover crop dry matter according to Tukey-HSD test $(p \leq 0.05)$. Different capital letters within one graph show significant differences concerning the weed dry matter according to Tukey-HSD test $(p \leq 0.05)$. Means for weed dry matter with no capital letters do not differ significantly. ${ }^{*}$ Due to space limitations in the graph (c): Control ${ }^{\mathrm{A}}$, A. graveolens $\mathrm{ABC}$, R. sativus ${ }^{\mathrm{BCD}}$, A. strigosa $^{\mathrm{D}}$, C. tinctorius $\mathrm{ABCD}$, V. sativa $\mathrm{AB}$, P. tanacetifolia $\mathrm{ABCD}$, Mixture $1 \mathrm{BCD}$, Mixture $2 \mathrm{ABCD}$, Mixture $3^{\mathrm{BCD}}$, Mixture $4{ }^{\mathrm{BCD}}$, Mixture $5 \mathrm{CD}$.

\subsection{Weed Control Efficacy}

In 2016, among the mixtures, the highest WCE was reached 12 WAS by the Mixture 4 treatment with $47 \%$ (Figure 4). Across all treatments, the R. sativus treatment had the highest WCE with $60 \%$. The highest WCE 12 WAS in 2017 among all treatments was reached by the $A$. strigosa treatment with 83\% 
followed by the treatments Mixture 1 and R. sativus with 75\% and 72\%, respectively. The differences in WCE between the treatments were not significant in 2016 and 2017 (12 WAS).
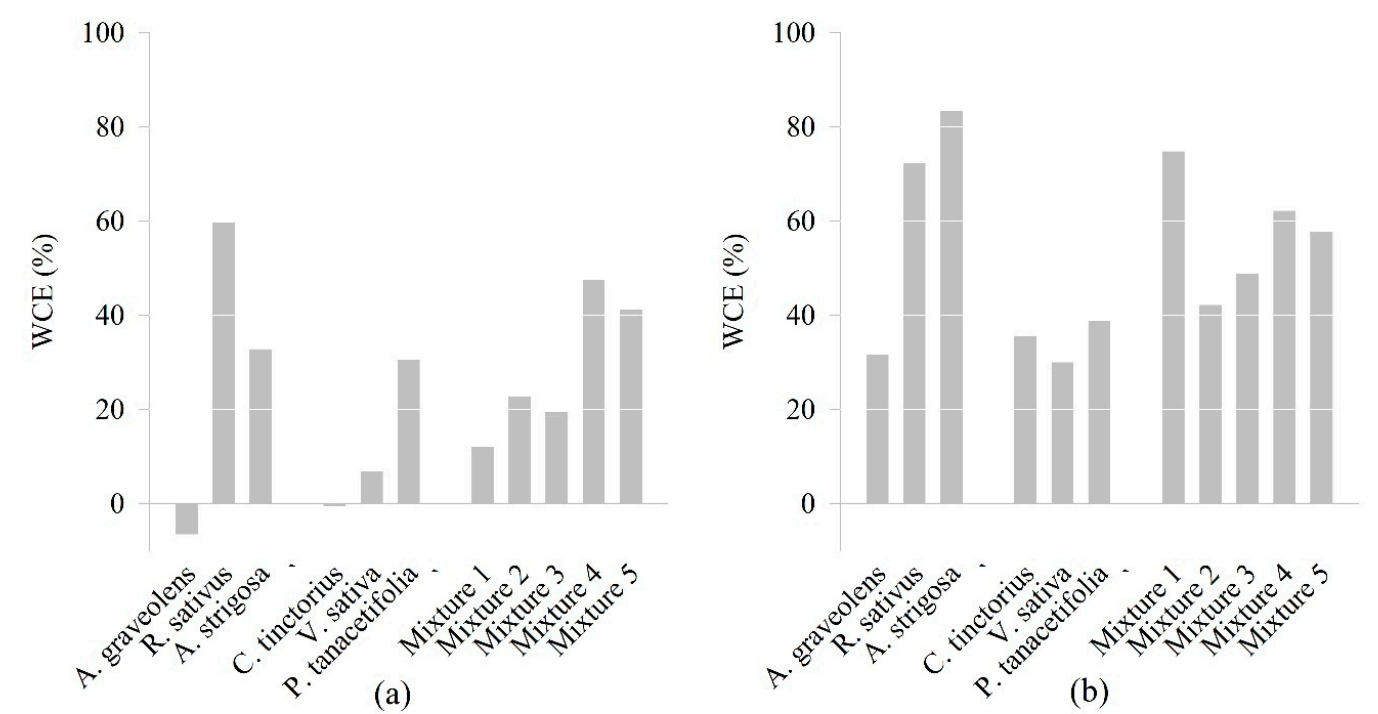

Figure 4. Weed control efficacy (WCE) of the six single sown and five cover crop mixtures 12 weeks after sowing in 2016 (a) and 2017 (b). Means with no letters do not differ significantly according to Tukey-HSD test $(p \leq 0.05)$.

\section{Discussion}

The highest WCE within both years was achieved by the A. strigosa treatment with $83 \%$ (12 WAS in 2017). Brust and Gerhards [47] showed a similarly high weed suppression ability of $A$. strigosa with $90 \%$. CCs seem to be able to significantly reduce the number of weeds but have not shown complete weed control within this study due to a severe drought period after sowing in 2016 and the generally high weed infestation in the 2017 season.

As expected, the CC dry matter is not necessarily a predictor of the weed suppression ability. No correlations between CC biomass and weed dry matter/density were determined. This agrees with Kunz et al. [34] and Baraibar et al. [2] who also did not find correlations between CC dry matter and weed density. Finney et al. [48] pointed out that biomass driven CCs do generally have a more effective weed suppression potential. However, it seems like this is only relevant to a certain extent. Gfeller et al. [7] name the threshold of $3 \mathrm{t} \mathrm{ha}^{-1}$, until which the CC biomass and the suppression of Amaranthus retroflexus L. were negatively correlated. Onwards, other parameters, like chemical or other physical parameters might have a higher importance to contribute to an efficient weed control. Within their study, also some CCs with low biomass yields, like Brassicaceae and A. strigosa, were able to achieve an efficient weed control against Amaranthus retroflexus L. [7]. This agrees with the data presented for the season 2016, whereby the A. strigosa treatment reached a WCE of 33\% (average WCE across all treatments: $24 \%$ ), with a simultaneously low amount of dry matter. This might be attributed to the allelopathic potential of $A$. strigosa [7,49]. R. sativus was, within the experiment, one of the most efficient single sown CC, reaching an average WCE within the two seasons of $66 \%$ (12 WAS). R. sativus is able to reach weed suppression efficacies of more than $90 \%[50,51]$ under ideal conditions and sowing dates. This is probably caused by the relatively high dry matter production (negative correlation between weed and brassica CC biomass [32]) and the well-reported allelopathic potential of Brassicaceae species [52,53].

Additionally, Brennan and Smith [9] and Dorn et al. [54] suggest that rapid plant development after sowing is more important than the final CC biomass [32]. For some examples, these results can be referred to the data presented. In late September 2017, the treatments $R$. sativus, A. strigosa and P. tanacetifolia showed the highest soil cover with $52-55 \%$. Both, the R. sativus and the A. strigosa 
treatment achieved the highest WCE among the single sown CCs with $72 \%$ and $83 \%$, respectively. In contrast, the $P$. tanacetifolia treatment, even though biomass and soil cover were well developed, performed as poorly as the very weak established treatments $A$. graveolens and $C$. tinctorius with less than $13 \%$ of soil cover.

The mixtures were not more efficient at suppressing weeds than the monocultures, which agrees with several studies $[32,48,55,56]$. The most efficient single sown CCs showed a higher suppression ability than the most efficient mixture in both years, which is also shown by Smith et al. [5]. According to Baraibar et al. [32], CC mixtures containing grasses are more efficient to suppress weeds than monocultures with Brassicaceae species or legumes. Within both years, all mixtures were clearly more efficient at suppressing weeds than V. sativa. This can be inferred from the studies of Baraibar et al. [32] and Hayden et al. [57], who conclude that CCs with early canopy closing, to which vetch does not belong, generally show better weed suppression. In 2016, the R. sativus treatment reached the highest WCE with 60\%, while in 2017 the Mixture 1 and the R. sativus treatment showed a similar WCE of $75 \%$ and $72 \%$, respectively. All other mixtures only reached a WCE between $42 \%$ and $62 \%$. Finney et al. [48] state as a reason that highly productive single sown CCs may produce as much biomass as diverse species mixtures. In October 2016 and 2017, particularly the single sown treatments like R. sativus and $P$. tanacetifolia were achieving higher dry matter yields than the mixtures. However, as discussed, the biomass of CC monocultures and mixtures is not, or only weakly, related to the weed suppression potential. Generally, species-specific mechanisms for weed suppression are still not well understood. How different mechanisms of weed suppression act or interact also need further investigation [32]. Even though mixtures might not be an improved tool for weed management in cover cropping systems, many other benefits are attributed to CC mixtures. In consideration of the dry matter, soil cover and the reduction of weeds during the 2016 season, the mixtures showed the ability to withstand unfavorable weather conditions better than many of the single sown CCs. The resilience of mixtures towards severe weather conditions or management errors [44], might compensate their less efficient weed control compared to monocultures. However, only high crop densities are an effective tool for weed suppression [58]. As species mixtures follow the idea to be able to buffer the failure of other species, increasing the sowing density of all species included in the mixture should be considered. This might be relevant in order to achieve similar crop stands under unfavorable conditions than within well-performing single sown treatments, resulting in an improved weed suppression potential.

The six species mixtures (Mixture 3-5) did not show a more efficient weed suppression potential than the three species mixtures (Mixture 1-2). As demonstrated by Kunz et al. [59], a five species mixture was not better than a mixture with seven species in terms of weed control. This leads to the conclusion that the quantity of plant species within a mixture is less relevant than the mixture composition. Brassicaceae and Poaceae species, for example, respond well to dry conditions, while Fabaceae species do not [24]. Mixture 1, with R. sativus, A. strigosa and A. graveolens showed the best weed control performance and was able to significantly reduce the weed density in both years compared to the control. Baraibar et al. [32] concluded that a high proportion of grass species achieves a large reduction of weed biomass, as grass species are also highly suppressive in monocultures. Mixtures with an increasing proportion of rye were able to decrease the weed biomass as observed by Akemo et al. [60]. This might be the reason why Mixture 1 with the highest proportion of $A$. strigosa performed best, while Mixture 2, as the only mixture without grass species, showed a comparably slow soil cover and weak WCE in 2017. Mixture 3-5 with different proportions of $A$. strigosa showed a reliable establishment and an adequate weed suppression ability. Sufficient weed control might already be provided by low proportions of grass species within mixtures, meanwhile other species may fulfill important ecosystem services [32].

\section{Conclusions}

Out of the two years of data presented, R. sativus and A. strigosa are the two most promising single sown CCs, because they showed a fast establishment along with the highest weed suppression potential. 
In order to fulfill the requirements of diverse ecosystem services and weed control, CC mixtures like Mixture 1 seem to be suitable for cover cropping. In general, mixtures need to be composed reasonably in order to avoid weed problems caused by poorly competitive species [61]. Combing CC species with physical and chemical weed suppression mechanisms may increase the weed control success. Species with chemical mechanisms thereby, for example, contribute to an efficient weed control under unfavorable circumstances when CC development and biomass yield is low. CC mixtures might substantially contribute to the success of biological weed control if the weed suppression mechanisms of different plant species and their ideal composition within mixtures can be identified.

Author Contributions: Conceptualization, A.S. and M.S.; Formal analysis, A.S.; Investigation, A.S.; Methodology, A.S.; Supervision, R.G.; Visualization, A.S.; Writing—original draft, A.S. and M.S.; Writing—review \& editing, R.G.

Funding: This research was financially supported by the "Ministerium für Ländlichen Raum, Ernährung und Verbraucherschutz Baden-Württemberg (MLR)" within the project "Conservation Agriculture" and the Research Training Group "Water-People-Agriculture" at the University of Hohenheim funded by the Anton \& Petra-Ehrmann foundation.

Acknowledgments: Thanks to the support from the research station "Ihinger Hof" and the Weed Science group of the University of Hohenheim. Thanks to Jacob Weiner for his constructive comments concerning the analysis and visualization of the data. Additionally, we thank Gerassimos G. Peteinatos for manuscript revision and Charlotte Hein for data acquisition.

Conflicts of Interest: The authors declare no conflict of interest.

\section{References}

1. European Parliament of the Council. Regulation (EU) No 1307/2013 of the European Parliament of the Council of 17 December 2013; Establishing Rules for Direct Payments to Farmers under Support Schemes within the Framework of the Common Agricultural Policy and Repealing Council Regulation (EC) No 637/2008 and Council Regulation (EC) No 73/2009.63; European Parliament of the Council: Brussels, Belgium, 2013.

2. Hartwig, N.L.; Ammon, H.U. Cover crops and living mulches. Weed Sci. 2002, 50, 688-699. [CrossRef]

3. Ellis, K.E.; Barbercheck, M.E. Management of overwintering cover crops influences floral resources and visitation by native bees. Environ. Entomol. 2015, 44, 999-1010. [CrossRef] [PubMed]

4. Dunbar, M.W.; Gassmann, A.J.; O'Neal, M.E. Limited impact of a fall-seeded, spring-terminated rye cover crop on beneficial arthropods. Environ. Entomol. 2017, 46, 284-290. [CrossRef] [PubMed]

5. Fourie, H.; Ahuja, P.; Lammers, J.; Daneel, M. Brassicacea-based management strategies as an alternative to combat nematode pests: A synopsis. Crop Prot. 2016, 80, 21-41. [CrossRef]

6. Farooq, M.; Jabran, K.; Cheema, Z.A.; Wahid, A.; Siddique, K.H.M. The role of allelopathy in agricultural pest management. Pest Manag. Sci. 2011, 67, 493-506. [CrossRef] [PubMed]

7. Gfeller, A.; Herrera, J.M.; Tschuy, F.; Wirth, J. Explanations for Amaranthus retroflexus growth suppression by cover crops. Crop Prot. 2018, 104, 11-20. [CrossRef]

8. Blanco-Canqui, H.; Shaver, T.M.; Lindquist, J.L.; Shapiro, C.A.; Elmore, R.W.; Francis, C.A.; Hergert, G.W. Cover crops and ecosystem services: Insights from studies in temperate soils. Agron. J. 2015, 107, 2449-2474. [CrossRef]

9. Brennan, E.B.; Smith, R.F. Winter cover crop growth and weed suppression on the central coast of California. Weed Technol. 2005, 19, 1017-1024. [CrossRef]

10. Creamer, N.G.; Bennett, M.A.; Stinner, B.R.; Cardina, J.; Regnier, E.E. Mechanisms of weed suppression in cover crop-based production systems. HortScience 1996, 31, 410-413. [CrossRef]

11. Putnam, A.R.; DeFrank, J.; Barnes, J.P. Exploitation of allelopathy for weed control in annual and perennial cropping systems. J. Chem. Ecol. 1983, 9, 1001-1010. [CrossRef]

12. Tabaglio, V.; Marocco, A.; Schulz, M. Allelopathic cover crop of rye for integrated weed control in sustainable agroecosystems. Ital. J. Agron. 2013, 8, e5. [CrossRef]

13. Teasdale, J.R.; Mohler, C.L. Light transmittance, soil temperature, and soil moisture under residue of hairy vetch and rye. Agron. J. 1993, 85, 673-680. [CrossRef]

14. Teasdale, J.R.; Beste, C.E.; Potts, W.E. Response of weeds to tillage and cover crop residue. Weed Sci. 1991, 39, 195-199. [CrossRef] 
15. Wayman, S.; Cogger, C.; Benedict, C.; Collins, D.; Burke, I.; Bary, A. Cover crop effects on light, nitrogen, and weeds in organic reduced tillage. Agroecol. Sustain. Food Syst. 2015, 39, 647-665. [CrossRef]

16. Falquet, B.; Gfeller, A.; Pourcelot, M.; Tschuy, F.; Wirth, J. Weed suppression by common buckwheat: A review. Environ. Control Biol. 2015, 53, 1-6. [CrossRef]

17. Belz, R.G. Allelopathy in crop/weed interactions-an update. Pest Manag. Sci. 2007, 63, 308-326. [CrossRef] [PubMed]

18. Hiltbrunner, J.; Liedgens, M.; Bloch, L.; Stamp, P.; Streit, B. Legume cover crops as living mulches for winter wheat: Components of biomass and the control of weeds. Eur. J. Agron. 2007, 26, 21-29. [CrossRef]

19. Hajjar, R.; Jarvis, D.I.; Gemmill-Herren, B. The utility of crop genetic diversity in maintaining ecosystem services. Agric. Ecosyst. Environ. 2008, 123, 261-270. [CrossRef]

20. Tilman, D.; Reich, P.B.; Knops, J.; Wedin, D.; Mielke, T.; Lehman, C. Diversity and productivity in a long-term grassland experiment. Science 2001, 294, 843-845. [CrossRef]

21. Finckh, M.; Gacek, E.; Goyeau, H.; Lannou, C.; Merz, U.; Mundt, C.; Munk, L.; Nadziak, J.; Newton, A.; de Vallavieille-Pope, C.; et al. Cereal variety and species mixtures in practice, with emphasis on disease resistance. Agronomie 2000, 20, 813-837. [CrossRef]

22. Huston, M.A. Hidden treatments in ecological experiments: Re-evaluating the ecosystem function of biodiversity. Oecologia 1997, 110, 449-460. [CrossRef] [PubMed]

23. Tilman, D.; Lehman, C.L.; Thomson, K.T. Plant diversity and ecosystem productivity: Theoretical considerations. Proc. Natl. Acad. Sci. USA 1997, 94, 1857-1861. [CrossRef] [PubMed]

24. Tribouillois, H.; Dürr, C.; Demilly, D.; Wagner, M.-H.; Justes, E. Determination of germination response to temperature and water potential for a wide range of cover crop species and related functional groups. PLoS ONE 2016, 11, e0161185. [CrossRef] [PubMed]

25. Constantin, J.; Le Bas, C.; Justes, E. Large-scale assessment of optimal emergence and destruction dates for cover crops to reduce nitrate leaching in temperate conditions using the STICS soil-crop model. Eur. J. Agron. 2015, 69, 75-87. [CrossRef]

26. Stott, P.A.; Stone, D.A.; Allen, M.R. Human contribution to the European heatwave of 2003. Nature 2004, 432, 610-614. [CrossRef] [PubMed]

27. MacArthur, R.; Levins, R. The limiting similarity, convergence, and divergence of coexisting species. Am. Nat. 1967, 101, 377-385. [CrossRef]

28. Abraham, C.T.; Singh, S.P. Weed management in sorghum-legume intercropping systems. J. Agric. Sci. 1984, 103, 103-115. [CrossRef]

29. Tribouillois, H.; Fort, F.; Cruz, P.; Charles, R.; Flores, O.; Garnier, E.; Justes, E. A functional characterisation of a wide range of cover crop species: Growth and nitrogen acquisition rates, leaf traits and ecological strategies. PLoS ONE 2015, 10, e0122156. [CrossRef]

30. Ofori, F.; Stern, W.R. Cereal-legume intercropping systems. Advances in Agronomy 1987, 41, 41-90.

31. Brainard, D.C.; Bellinder, R.R.; Kumar, V. Grass-Legume mixtures and soil fertility affect cover crop performance and weed seed production. Weed Technol. 2011, 25, 473-479. [CrossRef]

32. Baraibar, B.; Hunter, M.C.; Schipanski, M.E.; Hamilton, A.; Mortensen, D.A. Weed suppression in cover crop monocultures and mixtures. Weed Sci. 2018, 66, 121-133. [CrossRef]

33. Inderjit; Asakawa, C. Nature of interference potential of hairy vetch (Vicia villosa Roth) to radish (Raphanus sativus L.): Does allelopathy play any role? Crop Prot. 2001, 20, 261-265. [CrossRef]

34. Kunz, C.; Sturm, D.J.; Varnholt, D.; Walker, F.; Gerhards, R. Allelopathic effects and weed suppressive ability of cover crops. Plant Soil Environ. 2016, 62, 60-66.

35. Tschuy, F.; Gfeller, A.; Azevedo, R.; Khamissé, C.; Henriet, L.; Wirth, J. Weed suppression by cover crops: Analyzing different factors. Agrar. Schweiz 2014, 5, 292-299.

36. Sturm, D.J.; Peteinatos, G.; Gerhards, R. Contribution of allelopathic effects to the overall weed suppression by different cover crops. Weed Res. 2018, 58, 331-337. [CrossRef]

37. Teasdale, J.R. Contribution of cover crops to weed management in sustainable agricultural systems. J. Prod. Agric. 1996, 9, 475-479. [CrossRef]

38. Hooper, D.U.; Chapin, F.S.; Ewel, J.J.; Hector, A.; Inchausti, P.; Lavorel, S.; Lawton, J.H.; Lodge, D.M.; Loreau, M.; Naeem, S. Effects of biodiversity on ecosystem functioning: A consensus of current knowledge. Ecol. Monogr. 2005, 75, 3-35. [CrossRef] 
39. Tilman, D. The ecological consequences of changes in biodiversity: A search for general principles. Ecology 1999, 80, 1455-1474. [CrossRef]

40. Hector, A.; Schmid, B.; Beierkuhnlein, C.; Caldeira, M.C.; Diemer, M.; Dimitrakopoulos, P.G.; Finn, J.A.; Freitas, H.; Giller, P.S.; Good, J. Plant diversity and productivity experiments in European grasslands. Science 1999, 286, 1123-1127. [CrossRef]

41. Prieto, I.; Violle, C.; Barre, P.; Durand, J.-L.; Ghesquiere, M.; Litrico, I. Complementary effects of species and genetic diversity on productivity and stability of sown grasslands. Nat. Plants 2015, 1, 15033. [CrossRef]

42. Blesh, J. Functional traits in cover crop mixtures: Biological nitrogen fixation and multifunctionality. J. Appl. Ecol. 2018, 55, 38-48. [CrossRef]

43. Finney, D.M.; Kaye, J.P. Functional diversity in cover crop polycultures increases multifunctionality of an agricultural system. J. Appl. Ecol. 2017, 54, 509-517. [CrossRef]

44. Wortman, S.E.; Francis, C.A.; Bernards, M.L.; Drijber, R.A.; Lindquist, J.L. Optimizing cover crop benefits with diverse mixtures and an alternative termination method. Agron. J. 2012, 104, 1425-1435. [CrossRef]

45. Holmes, A.A.; Thompson, A.A.; Wortman, S.E. Species-specific contributions to productivity and weed suppression in cover crop mixtures. Agron. J. 2017, 109, 2808-2819. [CrossRef]

46. Rasmussen, J. A model for prediction of yield response in weed harrowing. Weed Res. 1991, 31, 401-408. [CrossRef]

47. Brust, J.; Gerhards, R. Lopsided oat (Avena strigosa) as a new summer annual cover crop for weed suppression in Central Europe. Jul. Kühn Arch. 2012, 257, 257-264.

48. Finney, D.M.; White, C.M.; Kaye, J.P. Biomass production and carbon/nitrogen ratio influence ecosystem services from cover crop mixtures. Agron. J. 2016, 108, 39-52. [CrossRef]

49. Rueda-Ayala, V.; Jaeck, O.; Gerhards, R. Investigation of biochemical and competitive effects of cover crops on crops and weeds. Crop Prot. 2015, 71, 79-87. [CrossRef]

50. Brust, J.; Claupein, W.; Gerhards, R. Growth and weed suppression ability of common and new cover crops in Germany. Crop Prot. 2014, 63, 1-8. [CrossRef]

51. Sturm, D.J.; Kunz, C.; Peteinatos, G.; Gerhards, R. Do cover crop sowing date and fertilization affect field weed suppression? Plant Soil Environ. 2017, 63, 82-88.

52. Haramoto, E.R.; Gallandt, E.R. Brassica cover cropping: I. Effects on weed and crop establishment. Weed Sci. 2005, 53, 695-701. [CrossRef]

53. Petersen, J.; Belz, R.; Walker, F.; Hurle, K. Weed suppression by release of isothiocyanates from turnip-rape mulch. Agron. J. 2001, 93, 37-43. [CrossRef]

54. Dorn, B.; Jossi, W.; van der Heijden, M.G.A. Weed suppression by cover crops: Comparative on-farm experiments under integrated and organic conservation tillage. Weed Res. 2015, 55, 586-597. [CrossRef]

55. Brust, J.; Weber, J.; Gerhards, R. Do cover crop mixtures have the same ability to suppress weeds as competitive monoculture cover crops? Jul. Kühn Arch. 2014, 2014, 422-430.

56. Smith, R.G.; Atwood, L.W.; Warren, N.D. Increased productivity of a cover crop mixture is not associated with enhanced agroecosystem services. PLoS ONE 2014, 9, e97351. [CrossRef] [PubMed]

57. Hayden, Z.D.; Brainard, D.C.; Henshaw, B.; Ngouajio, M. Winter annual weed suppression in rye-vetch cover crop mixtures. Weed Technol. 2012, 26, 818-825. [CrossRef]

58. Weiner, J.; Andersen, S.B.; Wille, W.K.-M.; Griepentrog, H.W.; Olsen, J.M. Evolutionary agroecology: The potential for cooperative, high density, weed-suppressing cereals. Evol. Appl. 2010, 3, 473-479. [CrossRef] [PubMed]

59. Kunz, C.; Sturm, D.J.; Sökefeld, M.; Gerhards, R. Weed suppression and early sugar beet development under different cover crop mulches. Plant Prot. Sci. 2017, 53, 187-193.

60. Akemo, M.C.; Regnier, E.E.; Bennett, M.A. Weed suppression in spring-sown rye (Secale cereale)-pea (Pisum sativum) cover crop mixes. Weed Technol. 2000, 14, 545-549. [CrossRef]

61. McLaren, C.; Swanwpoel, P.A.; Bennet, J.E. Cover crop biomass production is more important than diversity for weed suppression. Crop Sci. 2019, 59, 733-748. [CrossRef]

(C) 2019 by the authors. Licensee MDPI, Basel, Switzerland. This article is an open access article distributed under the terms and conditions of the Creative Commons Attribution (CC BY) license (http://creativecommons.org/licenses/by/4.0/). 